\title{
Active management of third stage of labor
}

\author{
Meena Thapa, Rachana Saha, Sumita Pradhan, Sushil Thakur, Archan Shamsher Rana \\ Kathmandu Medical College Teaching Hospital, \\ Sinamangal, Kathmandu, Nepal
}

\begin{abstract}
:
Objective: Overall objective of the study was to see effects of active management of third stage of labour (AMSTL) with oxytocin. Specific objective of the study was to look for incidence of Post-Partum Haemorrhage $(\mathrm{PPH})$, length of $3^{\text {rd }}$ stage, incidence of retained placenta and average blood loss.

Methodology: A hospital based prospective, descriptive, observational study was carried out from $1^{\text {st }}$ July 2005 to $30^{\text {th }}$ June 2006 at department of Obstetrics and Gynaecology, Kathmandu Medical College Teaching Hospital (KMCTH). All patients undergoing vaginal delivery excluding twins, polyhydraminios and instrumental deliveries were included in the study. The active management of $3^{\text {rd }}$ stage included administration of 10 units IU of oxytocin, early cord clamping, controlled cord traction and uterine massage. Blood loss was estimated by visual inspection and measured by jar pressed against perineum.

Result: Total number of deliveries during the study period was 530. There were 13 cases of PPH. Incidence of PPH was $2.4 \%$. There were six cases each of uterine atony and genital tract trauma. One case was of retained placenta requiring Manual Removal (MRP). Average third stage duration was less than 5 minutes. Average blood loss was $90 \mathrm{ml}$. In 2 cases the third stage lasted more than 30 mins.

Conclusion: Active management of $3^{\text {rd }}$ stage of labour reduces the incidence of PPH from uterine atony, reduces the duration as well as average blood loss during third stage.condition.
\end{abstract}

Key words: Labor analgesia; epidural, combined spinal epidural; complications, dural puncture, postdural puncture headache (PDPH); prevention.

\section{Introduction:}

Delivery of the placenta and membranes (The third stage of labour) is potentially the most hazardous stage of childbirth for the mother, mainly because of the risk of post-partum haemorrhage and it's subsequent morbidity. This stage of labour can be managed actively or expectantly. Active management involves prophylactic administration of an uterotonic agent, early cord-clamping and cutting, and controlled cord traction. ${ }^{1,2,3}$ and uterine massage. In expectant management (sometimes called conservative or physiological management) uterotonic drugs are not given prophylactically, the cord is neither clamped nor cut early and the placenta is expelled by maternal effort. ${ }^{1,2,3}$ From 1988 through 1998, four good quality large-scale randomized controlled studies conducted in well resourced maternity hospitals (two in the United Kingdom, one in the United Arab Emirates and one in Ireland) have compared the effects of active and expectant management of $3^{\text {rd }}$ stage of labour. Although the studies used different uterotonic drugs (oxytocin/ ergometrine either or both drugs) with different dosages and routes of administration and varied in the components of active management, their results were informative..$^{1,2,3}$ In all four studies, active management was associated with a decrease in PPH and a decrease in the length of $3^{\text {rd }}$ stage of labour. A Cochrane Library systematic review and meta-analysis concluded that active management of the third stage of labour in the setting of maternity hospital was superior to expectant management in reducing blood loss, post-partum haemorrhage and duration of $3^{\text {rd }}$ stage. Active management with ergometrine (compared to oxytocin), however was associated with an increase in nausea, vomiting and hypertension. Other studies have suggested that there are no advantages or disadvantages for the newborn and the uterotonic drugs are more effective in preventing PPH if they are administered before, rather than after, the placenta is delivered. ${ }^{1,2,3}$ In our hospital strict practice of AMSTL was started from $1^{\text {st }}$ July 2005.

\section{Correspondence}

Dr. Meena Thapa, Department of Obstetrics \& Gynaecology

Kathmandu Medical College Teaching Hospital, 184, Baburam Acharya Sadak,

Sinamangal - 9, Kathmandu, Nepal, Ph. No. 4481903 


\section{Objective:}

General: to observe the effects of active management of $3^{\text {rd }}$ stage of labour with oxytocin.

Specific objective: to determine the

1. Incidence of PPH

2. Length of $3^{\text {rd }}$ stage

3. Incidence of retained placenta

4. Average blood loss during third stage

\section{Methodology:}

A hospital based prospective, descriptive, observational study for a period of 1 year from $1^{\text {st }}$ July 2005 to $30^{\text {th }}$ June 2006 was carried out at the department of Obstetrics \& Gynaecology, KMCTH

Inclusion criteria: All vaginal delivery

Exclusion criteria: Twins, polyhydraminios, instrumental deliveries

\section{Administration of uterotonic drug:}

Within 1 minute of delivery of the baby, the abdomen is palpated to rule out the presence of an additional baby (s) and oxytocin 10 units $\mathrm{I} / \mathrm{M}$ is given.

\section{Early cord clamping:}

The cord is clamped close to the perineum

\section{Controlled cord traction:}

Controlled cord traction is performed after $2-3$ minutes of administration of syntocinon when strong uterine contraction occurs. If the placenta does not descend during $30-40$ seconds of controlled cord traction, the pull is discontinued and another contraction is awaited.

\section{Uterine massage:}

Uterus is massaged immediately through woman's abdomen until it is contracted for $1^{\text {st }}$ two hours done by the patient herself.

\section{Estimation of blood loss:}

Blood loss was measured by a jar pressed against perineum and visual inspection.

In our study there were 13 cases of post-partum haemorrhage out of 530 deliveries. Uterine atony and genital tract trauma were responsible equally (six cases each). There was one case of retained placenta requiring manual removal. Two cases had $3^{\text {rd }}$ stage of more than 30 minutes. Average duration of $3^{\text {rd }}$ stage was 5 minutes. Average blood loss was $90 \mathrm{ml}$. We used clinical estimation of blood loss which was an imperfect measure of the actual amount of blood loss but the basis on which clinical decision are usually made. Concern that active management increases the likelihood of placental entrapment are not supported by our data. When active and passive management of $3^{\text {rd }}$ stage are compared with Bristol and Hinching Brooke Trial there was definite decrease in incidence of PPH.(5.9\% Vs 17.9\%) in Birstol Trial (6.8\% Vs 16.5\%) in Hinching Brooke Trial. Our findings are consistent with the results of both.

\section{Result:}

Table 1: Type of delivery

\begin{tabular}{lr}
\hline Normal & 530 \\
LSCS & 228 \\
Instrumental & 32 \\
Twins & 4 \\
\hline
\end{tabular}

Table 2: causes of PPH

\begin{tabular}{lr}
\hline Cause of PPH & Number \\
\hline Uterine atony & 6 \\
Genital tract trauma & 6 \\
Retained placenta & 1 \\
Total & $\mathbf{1 3}$ \\
Incidence & $2.4 \%$ \\
\hline
\end{tabular}


Table 3: Comparison between KMCTH, Bristol Trial, Hitching Brooke Trial

\begin{tabular}{lccc}
\hline & KMCTH & Bristol Trial & Hitching Brooke Trial \\
\hline Incidence of PPH & $13 / 530(2.4 \%)$ & $50 / 846(5.91 \%)$ & $51 / 748(6.81 \%)$ \\
Average duration of $3^{\text {rd }}$ stage & 5 minutes & 5 minutes & 8 minutes \\
Duration of Third stage $>30$ & $2 / 530(0.37 \%)$ & $25 / 846(2.9 \%)$ & $25 / 748(3.31 \%)$ \\
Average blood loss & $90 \mathrm{ml}$. & $268.5 \mathrm{ml}$. & \\
\hline
\end{tabular}

\section{Conclusion:}

Numerous studies of the active management of $3^{\text {rd }}$ stage of labour and individual active management component support the effectiveness and the need to expand the use of active management of $3^{\text {rd }}$ stage of labour especially in developing country.

Out study concludes that active management reduces the incidence of PPH from uterine atony, reduces the duration and the average blood loss in $3^{\text {rd }}$ stage of labour

\section{References:}

1. Prendville WJ, Harding JE, Elbourno DR,
Stirrat GM. The Bristol $3^{\text {rd }}$ stage trial. Active vs physiologic management of $3^{\text {rd }}$ stage of labour. British Medical Journal 1998; 297:1295 1300.

2. Rogers J, Wood J, McCandeish R, Ayers S, Truesdale A, Elbourne D. Active versus expectant management of 3rd stage of labour: The Hinching Brooke randomised control trial lancet 1998; 351: 693-99.

3. Prendville WJ, Elbourne D,McDonald S. Active versus expectant management in the 3 rd stage of labour (Cochrane review). In the Cochrane Library, issue 1, 2003 Oxford: update Software. 